\title{
PENERAPAN SAN REMO MANUAL PADA PENGIRIMAN (SATGAS MTF) TNI DALAM MISI UNIFIL
}

\author{
Martha Latu Retno \\ Staf Personel Koarmatim \\ Jl. Raya Hangtuah Ujung Koarmatim Surabaya \\ Email: marthalatupurwokuntjoro@gmail.com
}

\begin{abstract}
At the year of 2009 for the first time Indonesia took part by send a warships (KRI) for peacekeeping mission in UNIFIL (United Nations Mission Interim Forces in Lebanon). The UNIFIL MTF's mission acted upon military operations other than war at sea were located in the area of conflict between Israel and Hezbollah. International legal provisions applicable to war at sea is the San Remo Manual which is a guideline for the implementation of war at sea. Therefore, it is necessary to study the legal status and how the implementation of the San Remo Manual can be used in military operations in the Task Force MTF UNIFIL mission. The purpose of writing is to examine and analyze the legal status of the Task Force and the military MTF identify and analyze the implementation of the San Remo Manual can be used in military operations in the Task Force MTF UNIFIL mission. This writing method normative legal writing approach Statute and philosophical approach. Of this paper will be the writing on the analysis results obtained legal status and application of the military task force MTF San Remo Manual can be used in the operation of the Task Force of UNIFIL MTF.
\end{abstract}

Key words: legal status of The MTF TNI's task force, the implementation of the san remo manual

\begin{abstract}
Abstrak
Pada tahun 2009 untuk pertama kalinya Indonesia mengirimkan Kapal Perang Republik Indonesia (KRI) dalam misi pemelihara perdamaian di bawah bendera PBB pada misi United Nation Interim Forces Mission in Lebanon (UNIFIL). Di dalam Satgas MTF TNI misi UNIFIL ini malaksanakan operasi militer selain perang di laut yang berada didaerah konflik antara Israel dan Hisbullah. Ketentuan hukum Internasional yang berlaku untuk perang di laut adalah San Remo Manual yang merupakan pedoman pelaksanaan perang di laut. Tujuan penulisan ini untuk mengetahui dan menganalisa status hukum Satgas MTF TNI serta mengetahui dan menganalisa penerapan San Remo Manual dapat digunakan dalam operasi Satgas MTF TNI dalam misi UNIFIL. Penulisan ini menggunakan metode penulisan hukum normatif yang menggunakan pendekatan undang-undang dan pendekatan filsafat. Dari penulisan ini akan diperoleh hasil penulisan mengenai analisis status hukum Satgas MTF TNI dan penerapan San Remo Manual dapat digunakan dalam operasi Satgas MTF UNIFIL.
\end{abstract}

Kata kunci: status hukum Satgas MTF TNI, penerapan san remo manual 


\section{Latar Belakang}

Sebagai negara kepulauan terbesar di dunia dengan 17.499 pulau panjang garis pantai mencapai $\pm 80.791 \mathrm{~km}$. Luas wilayah perairan yurisdiksi Indonesia $\pm 5,8$ juta $\mathrm{km}^{2}$ yang mencakup Laut Wilayah, Perairan Kepulauan dan Perairan Pedalaman seluas $\pm 2,7$ juta $\mathrm{km}^{2}$ serta perairan Zona Ekonomi Eksklusif seluas $\pm 3,1$ juta $\mathrm{km}^{2},{ }^{1}$ maka sepatutnyalah Indonesia memiliki Armada pertahanan maritim yang kuat. Armada pertahanan ini tidak hanya mampu menjaga kedaulatan wilayah yurisdiksinya namun juga dapat berperan baik dalam kancah regional dan global. Hal ini pulalah yang menjadi komitmen Indonesia sehingga pada tahun 2009 untuk pertama kalinya Indonesia mengirimkan Kapal Perang Republik Indonesia (KRI) dalam misi pemelihara perdamaian di bawah bendera

Gambar 1. Area of Maritime Operation MTF

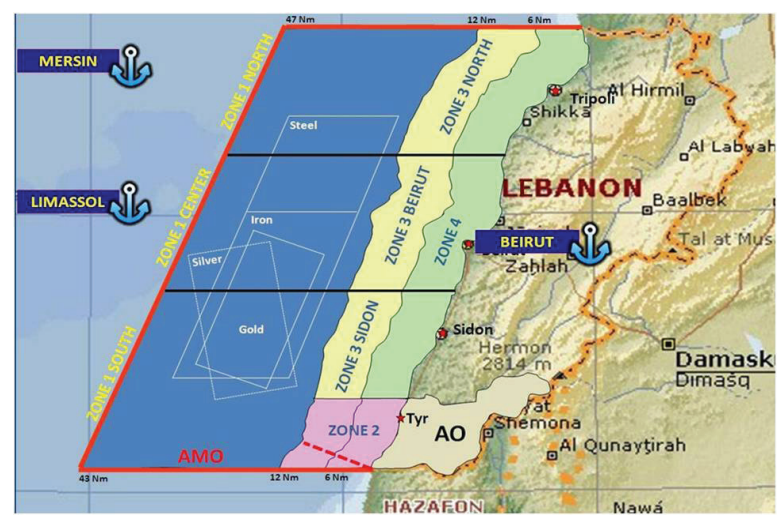

Sumber: Data Tersier Tahun 2010 ${ }^{3}$
Perserikatan Bangsa-bangsa/PBB pada misi UNIFIL (United Nations Interim Forces Mission in Lebanon) di Lebanon ${ }^{2}$.

Kebijakan pengiriman KRI sebagai Satgas MTF TNI merupakan kebijakan politik luar negeri yang tertuang dalam landasan yuridis Keputusan Presiden Nomor 15 Tahun 2006 tentang Kontingen Garuda dalam Misi Perdamaian di Lebanon. Secara konstitusional implementasi kebijakan ini sesuai dengan amanat Pembukaan Undang-undang 1945 Alinea IV. ${ }^{4}$

Sejak tahun 1957 Indonesia telah diundang secara aktif untuk berpartisipasi mengirimkan kontingen pasukan pemelihara perdamaian dibawah bendera PBB, namun pasukan yang dikirimkan adalah pasukan aspek darat yang berisi dari komposisi matra gabungan TNI Angkatan Darat, TNI Angkatan Laut dan TNI Angkatan Udara. Sedangkan Satgas MTF TNI ini hanya terdiri dari Prajurit TNI Angkatan Laut yang mengawaki KRI. Hal ini jelas menunjukan apresiasi dan kepercayaan dunia internasional kepada kekuatan pertahanan maritim Indonesia. Prestasi TNI Angkatan Laut merupakan wujud tuntutan tugas yang tertuang dalam pasal 9 huruf c Undangundang Nomor 34 tahun 2004 tentang TNI. ${ }^{5}$

1 Mabes TNI AL, Doktrin Eka Sasana Jaya, Mabes TNI AL, Jakarta, 2012, hlm. 6.

2 Yayan Sugiyana, Prajurit TNI Angkatan Laut dalam Misi Maritime Task Force (MTF), Edisi 423, Majalah Cakrawala, 2014, hlm. 21.

3 Didong Rio Duta, Laporan Pelaksanaan Tugas sebagai perwira staf Naval Operation Center/NOC UNIFIL, Mabes TNI, Jakarta, 2010, hlm. 3.

4 Alinea ke IV Pembukaan UUD 1945:“....ikut melaksanakan ketertiban dunia yang berdasarkan kemerdekaan, perdamaian abadi, dan keadilan sosial..."

5 Pasal 9 huruf c Undang-undang Nomor 34 Tahun 2004 tentang TNI: “Angkatan Laut melaksanakan tugas diplomasi yang membantu kepentingan politik luar negeri yang sudah ditentukan oleh pemerintah.” 
Implementasi kebijakan pemerintah untuk pengiriman satgas MTF TNI dalam misi UNIFIL ini tetap akan dilanjutkan sesuai dengan kesepakatan dalam Memorandum of Understanding/MoU antara pemerintah Indonesia sebagai Troop Contributing Country/ TCC dengan PBB yang tidak disebutkan batas waktunya. Sampai dengan saat ini pemerintah Indonesia tetap mengambil keputusan untuk mengirimkan KRI dalam misi tersebut, dan bahkan pada tahun 2015 ini kapal Korvet jenis SIGMA (Ship Integrated Modularity Approach) Kelas KRI Diponegoro-365 akan digantikan dengan kapal Fregat jenis Multi Role Light Fregate/MRLF kelas KRI Bung Tomo-357 yang baru dibeli dari Inggris untuk dikirim melaksanakan tugas di Lebanon ${ }^{6}$.

Sebagai tugas yang sangat bernilai strategis dan telah berlangsunglebih dari 5 tahun, maka perlu dilaksanakan penelitian sebagai upaya untuk meningkatkan peran serta TNI/TNI AL dalam tugas memelihara perdamaian dunia dimasa mendatang. Salah satunya penelitian aspek legal sebagai dasar yuridis pengiriman satuan TNI/TNI AL dalam tugas pemelihara perdamaian khususnya dibawah bendera PBB.

1. Bagaimana status hukum Satgas MTF TNI dalam misi UNIFIL di Lebanon?

2. Bagaimana penerapan San Remo Manual sebagai Hukum Internasional yang mengatur tentang Hukum perang dilaut dapat digunakan dalam operasi Satgas MTF TNI ?

Jenis penelitian dalam yang digunakan dalam penelitian tesis ini adalah penelitian hukum normatif. Peter Mahmud Marzuki mengemukakan bahwa, penelitian hukum merupakan proses menemukan aturan, prinsip maupun doktrin hukum yang digunakan untuk menjawab isu hukum yang ada, dan keberadaan penelitian hukum dilakukan dalam rangka untuk memperoleh argumentasi, teori atau konsep baru untuk pernyataan awal dalam memecahkan permasalahan yang dihadapi, sehingga jawaban yang diharapkan di dalam penelitian hukum adalah right, appropriate, inappropriate atau wrong ${ }^{7}$. Dengan demikian, penelitian hukum normatif adalah penelitian yang memberikan eksposisi sistematis tentang peraturan yang mengatur kategori hukum tertentu, menganalisis hubungan antara peraturan, menjelaskan area kesulitan dan, dapat juga memprediksi perkembangan di masa yang akan datang.

Pendekatan yang dipakai dalam penelitian ini adalah: Pendekatan undang-undang (statute approach), pendekatan filsafat (philosophical approach). Tujuan dari penggunaan pendekatan ini adalah:

1. Pendekatan undang-undang atau statute approach, ditujukan untuk melakukan evaluasi terhadap peraturan perundang-

6 Kepala Staf TNI Angkatan Laut, Telegram Kasal Nomor 130/Sops/0215 Twu 0203.1955, tentang penunjukan KRI Bung Tomo - 357 sebagai kapal kelas MRLF yang akan menggantikan KRI Sultan Iskandar Muda - 367 dari kelas SIGMA dalam Satgas Konga XXVIII-H/MTF TNI, Sopsal, Jakarta, 2015, hlm. 1.

7 Peter Mahmud Marzuki, Penelitian Hukum, Kencana Prenada Media Group, Jakarta, 2005, hlm. 35. 
undangan, yang menjadi landasan dan berhubungan dengan pengaturan mengenai status hukum dalam peraturan perundang-undangan yang ada. ${ }^{8}$ Pendekatan ini juga untuk menganalisa pentingnya penerapan San Remo Manual pada pengiriman Satgas MTF TNI dalam misi UNIFIL.

2. Pendekatan filsafat atau philosophical approach, digunakan untuk mengkaji eksistensi dan perkembangan nilai kepastian, keadilan dan manfaat, ${ }^{9}$ khususnya dalam penerapan San Remo Manual. Pendekatan filsafat ini menurut peneliti perlu dilakukan untuk mencari sebuah esensi, mengingat sifat filsafat adalah menyeluruh, mendasar dan spekulasi, menjadikan filsafat hukum menjelaskan persoalan hukumnya secara radikal dan mendalam. ${ }^{10}$

Bahan hukum adalah segala sesuatu yang dapat dipakai atau diperlukan untuk tujuaan menganalisis hukum yang berlaku. ${ }^{11}$ Bahan hukum yang dikaji terdiri atas:

a. Bahan hukum primer yaitu bahanbahan hukum yang berwujud peraturan perundang-undangan yang berlaku saat ini isinya mempunyai kekuatan mengikat. ${ }^{12}$ Dalam penelitian ini bahan hukum primer yang terdiri dari:

1) UUD 1945

2) Undang-Undang:

a. Undang-Undang Republik Indonesia Nomor 37 Tahun 1999 tentang Hubungan Luar Negeri

b. Undang-Undang Republik Indonesia Nomor 24 Tahun 2000 tentang Perjanjian Internasional.

c. Undang-Undang Republik Indonesia Nomor 3 Tahun 2002 tentang Pertahanan Negara.

d. Undang-Undang Republik Indonesia Nomor 34 Tahun 2004 tentang Tentara Nasional Indonesia.

3) Kepres Nomor 15 Tahun 2006 tentang Kontingen Garuda dalam Misi Perdamaian di Lebanon.

4) Mahkamah Internasional

5) Piagam PBB

6) UNCLOS TH 1982

7) San Remo Manual

8) Konvensi Jenewa

9) Doktrin yang berlaku di lingkungan TNI dalam rupa buku-buku petunjuk induk, pelaksanaan, operasi, taktis dan teknis yang digunakan dalam operasi Satgas MTF TNI.

b. Sedang Bahan Hukum Sekunder sejauh ada kaitannya dengan masalah yang diteliti, yang terdiri dari:

1. Buku-buku karya tulis dari kalangan ahli hukum yang membahas masalah hukum internasional.

8 Ibid., hlm. 136.

9 Johnny Ibrahim, Teori dan Metodologi Penelitian Hukum Normatif, Bayu Media Publishing, Malang, 2008, hlm. 300.

10 Darji Darmodiharjo \& Sidharta, Pokok-pokok Filsafat Hukum; Apa dan Bagaimana Filsafat Hukum Indonesia, Gramedia Pustaka Utama, Jakarta, 2004, hlm. 6.

11 Soerjono Soekanto dan Sri Mamuji, Penelitian HukumNormatif Suatu Tinjauan Singkat, RajaGrafindo Persada, Jakarta, 2010, hlm. 14.

12 Suratman dan Philips Dillah, Metode Penelitian Hukum, Alfabeta, Bandung, 2013, hlm. 67. 
2. Hasil penelitian yang pernah ada.

3. Publikasi-publikasi mutakhir. ${ }^{13}$

c. Sedangkan bahan hukum tersier, yaitu bahan hukum penunjang yang memberi petunjuk dan penjelasan terhadap bahan hukum primer dan bahan hukum sekunder, seperti kamus hukum, Surat kabar, majalah dan internet juga menjadi bahan bagi penelitian ini sepanjang memuat informasi yang relevan dengan obyek kajian penelitian ini. ${ }^{14}$

Upayamemperoleh suatukebenaranilmiah dalam penulisan tesis dengan pengumpulan bahan hukum primer, sekunder, dan tersier yang bersifat normatif dilakukan dengan cara penelusuran, pengumpulan, dan studi literatur dan dokumen, baik secara konvensional maupun dengan melalui internet.

Bahan-bahan hukum yang diperoleh dalam penelitian ini akan diinventarisasi dan diklasifikasi sesuai permasalah yang akan dibahas. Bahan hukum yang mempunyai hubungan dengan permasalahan yang akan dibahas selanjutnya dipaparkan dan disistematisasi, kemudian dianalisis untuk digunakan menginterprestasikan hukum yang berlaku (positive law) di dalam tesis ini. ${ }^{15}$

Tehnik pengumpulan bahan hukum. Bahan-bahan hukum yang bersifat normatif dianalisis dengan menggunakan metode normatif, yaitu metode doktrinal dengan optic prescriptive. Bahan-bahan yang telah dikumpulkan dan dinilai keabsahannya, selanjutnya diolah dengan cara diklasifikasi, dikategorikan, disistematisi dan diinterprestasi sesuai dengan masalah atau isu yang akan dibahas.

Setelah semua bahan hukum yang didapat dan terkumpul, data diolah dengan cara diseleksi menurut relevansinya sesuai dengan kerangka sementara yang telah disusun. Bahan hukum yang telah diolah kemudian dianalisis, dibahas dengan cara menghubungkan kembali pada kerangka dan tujuan penelitian sehingga diperoleh kesimpulan sebagai hasil dan suatu penelitian.

\section{Pembahasan}

\section{A. Status Hukum Satgas MTF TNI}

\section{Politik luar negeri}

Politik luar negeri yang dianut oleh Indonesia adalah bebas dan aktif yang tercantum didalam penjelasan umum huruf d Undang-undang Nomor 3 tahun 2002 tentang pertahanan negara. ${ }^{16} \mathrm{Hal}$ ini menjadi landasan untuk menggunakan TNI sebagai komponen utama pertahanan negara untuk

13 Salim dan Erlies Septiana Nurbani, Penerapan Teori Hukum Pada Penelitian Tesis dan Desertasi, RajaGrafindo Persada, Jakarta, 2014, hlm. 16.

14 Dyah Ochtorina Susanti dan A’an Efendi, Penelitian Hukum, Sinar Grafika, Jakarta, 2014, hlm. 53.

15 Zainuddin, Metode Penelitian Hukum, Sinar Grafika, Jakarta, 2009, hlm. 176.

16 Penjelasan umum huruf d Undang-undang Nomor 3 Tahun 2002 tentang Pertahanan: “Bangsa Indonesia menentang segala bentuk penjajahan dan menganut politik bebas aktif. Untuk itu, pertahanan negara ke luar bersifat defensif aktif yang berarti tidak agresif dan tidak ekspansif sejauh kepentingan nasional tidak terancam. Atas dasar sikap dan pandangan tersebut, bangsa Indonesia tidak terikat atau ikut serta dalam suatu pakta pertahanan dengan negara lain" 
secara konsisten terlibat dalam berbagai misi perdamaian dunia. Kemudian dalam doktrin petunjuk induk TNI tentang operasi disebutkan bahwa TNI sebagai komponen utama pertahanan negara ikut serta menjadi alat negara di bidang pertahanan untuk menjalankan tugasnya didasarkan atas kebijakan dan keputusan politik negara. ${ }^{17}$ Oleh karena itu secara jelas dapat dilihat bagaimana keterlibatan peran TNI dalam implementasi politik luar negeri yang bebas aktif ini.

\section{Konsistensi Indonesia dalam misi pemelihara perdamaian $\mathrm{PBB}$}

Keikutsertaan TNI sejak tahun 1957 melalui Kontingen Garuda I (KONGA I) di Mesir hingga yang terakhir di Lebanon melalui Kontingen Garuda XXVIII/MTF TNI, menunjukkan komitmen yang tinggi dari bangsa Indonesia untuk memperjuangkan perdamaian dunia yang abadi. Prestasi Kontingen Garuda sebagai pasukan pemelihara perdamaian yang membanggakan tersebut semakin membangun ke-percayaan dunia terhadap kemampuan Indonesia dalam mengelola pertahanannya serta memberikan kontribusi bagi perdamaian dunia ${ }^{18}$.

Sejak tahun 1957 Indonesia telah diundang secara aktif untuk berpartisipasi mengirimkan kontingen pasukan pemelihara perdamaian dibawah bendera PBB, namun pasukan yang dikirimkan adalah hanya pasukan matra darat yang berisi dari komposisi matra gabungan TNI Angkatan Darat, TNI Angkatan Laut dan TNI Angkatan Udara. Sedangkan Satgas MTF TNI ini hanya terdiri dari Prajurit TNI Angkatan Laut yang mengawaki KRI. Hal ini jelas menunjukan apresiasi dan kepercayaan dunia internasional kepada kekuatan pertahanan maritim Indonesia. Prestasi TNI Angkatan Laut merupakan wujud tuntutan tugas yang tertuang dalam pasal 9 huruf c Undang-undang Nomor 34 tahun 2004 tentang TNI. ${ }^{19}$

Implementasi kebijakan pemerintah untuk pengiriman satgas MTF TNI dalam misi UNIFIL ini tetap akan dilanjutkan sesuai dengan kesepakatan dalam Memorandum of Understanding/MoU antara pemerintah Indonesia sebagai Troop Contributing Country/ TCC dengan PBB yang tidak disebutkan batas waktunya. Sampai dengan saat ini pemerintah Indonesia tetap mengambil keputusan untuk mengirimkan KRI dalam misi tersebut.

Bahkan pada tahun 2015 ini kapal Korvet jenis SIGMA (Ship Integrated Modularity Approach) yaitu KRI Sultan Iskandar Muda - 367 akan digantikan dengan kapal Fregat KRI Bung Tomo-357 dari jenis Multi Role Light Fregate/MRLF yang baru dibeli dari Inggris untuk dikirim melaksanakan tugas di Lebanon $^{20}$.

17 Mabes TNI, Op.cit., hlm. 4.

18 Departemen Pertahanan RI., Strategi Pertahanan, Departemen Pertahanan, Peraturan Menteri Pertahanan Nomor: Per/22/M/XII/2007 tanggal 28 Desember 2007, Dephan, Jakarta, 2007, hlm. 119.

19 Pasal 9 huruf c Undang-undang Nomor 34 Tahun 2004 tentang TNI: “Angkatan Laut melaksanakan tugas diplomasi yang membantu kepentingan politik luar negeri yang sudah ditentukan oleh pemerintah."

20 Kepala Staf TNI Angkatan Laut, Loc.cit., hlm. 1. 
3. Tujuan dan kepentingan nasional Indonesia

Tugas pokok TNI sebagai alat pertahanan negara berpangkal tolak pada falsafah dan pandangan hidup bangsa Indonesia yang disebutkan untuk menjamin utuh dan tegaknya Negara Kesatuan Republik Indonesia berdasarkan Pancasila dan konstitusi Undangundang Dasar $1945^{21}$. Oleh karena itu tugas pokok TNI dijabarkan menurut tujuan dan kepentingan nasional Indonesia. Sehingga secara normatif hukum, disitulah dasar utama keterlibatan Indonesia dalam misi pemerlihara perdamaian di bawah bendera PBB. Tujuan dan kepentingan nasional ini merupakan pokok atau "pondasi" bagaimana operasi militer sebagai keputusan politik negara digelar, baik dalam bentuk operasi militer untuk perang (OMP) maupun operasi militer selain perang $(\mathrm{OMSP})^{22}$.

Dimana dalam operasi militer untuk perang (OMP) dapat dijelaskan adalah sebagai segala macam pengerahan dan penggunaan kekuatan TNI, untuk melawan kekuatan militer negara lain yang melakukan tindakan agresi terhadap Indonesia, dan atau didalam konflik bersenjata dengan satu negara lain atau lebih, yang dimulai dengan adanya pernyataan perang dan tunduk pada ketentuan hukum perang internasional. ${ }^{23}$ Sedangkan Operasi Militer Selain Perang (OMSP) adalah merupakan operasi militer yang dilaksanakan bukan dalam rangka perang dengan negara lain, melainkan untuk tugas-tugas seperti melawan pemberontakan bersenjata, gerakan separatis, tugas mengatasi kejahatan lintas negara, bantuan kemanusiaan dan tugas perdamaian. ${ }^{24}$ Sehingga operasi pemelihara perdamaian dibawah bendera PBB merupakan bagian tugas pokok TNI sebagai penjabaran tujuan dan kepentingan nasional Indonesia.

\section{Hukum nasional}

Hukum nasional itu ada dan berlaku di dalam suatu negara sehingg mengatur segala hubungan dan kejadian didalam wilayah negara tersebut. Dalam sistem hukum nasional Indonesia, pengiriman Satgas TNI dalam misi PBB oleh Mabes TNI telah diatur dalam Peraturan Panglima TNI Nomor: Perpang/80/XII/2009 tanggal 1 Desember 2009 tentang Buku Petunjuk Pelaksanaan TNI tentang23Penyelenggaraan Operasi Perdamaian Dunia. Dimana ketentuanketentuan dasar hukum nasional yang digunakan sebagai dasar adalah sebagai berikut:
a. Undang-Undang RI Nomor 37 Tahun 1999 tentang Hubungan Luar Negeri;
b. Undang-Undang RI Nomor 24 Tahun 2000 tentang Perjanjian;
c. Keputusan Panglima TNI Nomor Kep/02/I/2007 tanggal 12 Januari 2007 tentang Doktrin Tentara Nasional

21 Pertimbangan huruf b Undang-undang Nomor 3 Tahun 2002 tentang Pertahanan Negara.

22 Mabes TNI., Buku Petunjuk Induk tentang Operasi TNI Peraturan Panglima TNI Nomor Perpang/31/V/2008 Tanggal 22 Mei 2008, Mabes TNI Cilangkap, Jakarta, 2008, hlm. 8.

23 Ibid., hlm. 3.

24 Ibid. 
Indonesia Tri Dharma Eka Karma (Tridek);

d. Peraturan Panglima TNI Nomor Perpang/32/VI/2009 tanggal 29 Juni 2009 tentang Bujuklak Perjanjian Internasional di Lingkungan Tentara Nasional Indonesia;

e. Keputusan Panglima TNI Nomor Kep/4///2007 tanggal 29 Januari 2007 tentang Pokok-Pokok Organisasi PMPP TNI;

f. Keputusan Panglima TNI Nomor Kep/5/I/2007 tanggal 29 Januari 2007 tentang Pembentukan Organisasi PMPP TNI."

Hingga saat ini dasar tersebut masih digunakan, sehingga dengan bertambahnya peraturan perundang-undangan yang berlaku perlu kiranya aturan ini direvisi untuk validasi legal aspect pengiriman Satgas TNI dalam misi PBB.

\section{Hukum nasional sebagai landasan keterlibatan satuan TNI khususnya TNI AL dalam misi PBB}
a. Pembukaan UUD 1945
b. Undang-Undang RI Nomor 3 Tahun 2002 tentang Pertahanan Negara
c. Undang-Undang RI Nomor 34 Tahun 2004 tentang Tentara Nasional Indonesia.
d. Undang-Undang RI Nomor 37 Tahaaun 1999 tentang Hubungan Luar Negeri
e. Keputusan Presiden Nomor 15 tahun 2006 tentang Kontingen Garuda dalam Misi Perdamaian di Lebanon
f. Doktrin TNI Tri Dharna Eka Karma (Tridek)
g. Operasional pelibatan Satuan TNI dalam Misi PBB.
h. Pokok-pokok pengiriman Satgas MTF TNI dalam Operasi Pemelihara Perdamaian PBB

\section{Hukum Internasional}

Sesuai dengan Peraturan Panglima TNI Nomor: Perpang/80/XII/2009 tanggal 1 Desember 2009 tentang Buku Petunjuk Pelaksanaan TNI tentang Penyelenggaraan Operasi Perdamaian Dunia hanya disebutkan Piagam Perserikatan Bangsa-Bangsa (PBB) dan MoU antara pemerintah Indonesia dengan PBB tentang pengiriman satuan tugas TNI pada setiap misi operasi perdamaian dunia. Hal ini dapat dikaji bahwa internasional legal aspect yang mendasari perlu ditambahkan dengan berbagai konvenan-konvenan lainnya. Namun sebelum membahas lebih jauh perlu terlebih dahulu dijelaskan dalam kajian pustaka pentingnya hukum internasional digunakan sebagai dasar pengiriman pasukan TNI dalam operasi pemelihara perdamaian di bawah bendera PBB.

Mengingat bahwa hukum internasional itu dibuat oleh negara-negara, baik melalui hukum kebiasaan maupun hukum tertulis dan karena negara-negara itu merupakan pelaku dan juga sekaligus pengawas dari implementasi hukum tersebut, tentu saja hukum internasional ini tidak sekuat jika dibandingkan dengan hukum nasional.

Beberapa peraturan dalam hukum Internasional yang digunakan sebagai dasar pengiriman Satgas Konga TNI Chapter VI dan VII dari piagam $\mathrm{PBB}^{25}$. Secara khusus pada Peraturan Panglima TNI Nomor perpang/80/ XII/2009 tanggal 1 Desember 2009 tentang 
Buku Petunjuk Pelaksanaan TNI tentang Penyelenggaraan Operasi Perdamaian Dunia, peraturan dalam hukum Internasional yang digunakan dalam buku petunjuk tersebut hanya disebutkan:

a. Piagam Perserikatan Bangsa-Bangsa (PBB).

b. MoU antara pemerintah Indonesia dengan PBB tentang pengiriman satuan tugas TNI pada setiap misi operasi perdamaian dunia.

Sehingga perlu kiranya dilengkapi dengan peraturan hukum Internasional yang dapat digunakan sebagai dasar, antara lain:

a. United Nations Convention on The Law of the Sea 1982, merupakan kovensi tentang hukum laut yang telah diratifikasi oleh 172 negara yang mengikuti konvensi tersebut.

b. San Remo Manual, merupakan manual yang membatasi penggunaan senjata dalam perang di laut.

c. Konvensi Jenewa tentang Hukum perang dan protokol-protokol tambahannya sebagai Hukum Perang Internasional.

7. Hukum internasional sebagai landasaan keterlibatan satuan TNI khususnya TNI AL dalam misi PBB
a. Piagam $\mathrm{PBB} / U N$ Charter
b. Konvensi Jenewa 1949 dan protokol Tambahan
c. UNCLOS

\section{Hubungan antara hukum internasional dan hukum nasional}

Hubungan hukum ini ada dua aliran: monisme dan dualisme. Berdasarkan pandangan monisme ini, hukum internasional dan nasional merupakan bagian dari satu sistem hukum pada umumnya. Semua ketentuan hukum merupakan satu kesatuan sistem yang terdiri dari ketentuan-ketentuan hukum yang mengikat terhadap negara, individu maupun kesatuan bukan negara.

Hukum nasional maupun hukum internasional masing-masing merupakan dua aspek dari satu sistem hukum tersebut, yang secara keseluruhan merupakan bagian dari sistem hukum universal yang mengikat manusia baik secara individual maupun secara kolektif. Hukum internasioanl mengikat individu secara kolektif sedangkan hukum nasional mengikat individu secara perorangan. Sedangkan teori dualisme beranggapan bahwa hukum internasional dan hukum nasional masing-masing merupakan dua sistem hukum yang berbeda secara intrinsik. Hukum nasional berbeda dengan hukum internasional karena berbeda subyek maupun sumbernya. Subyek hukum internasional hanya negara, sedangkan subyek hukum nasional adalah individu. ${ }^{26}$ Aliran dualisme ini telah dibantah oleh monisme dengan alasan yaitu: 
a. Kedua sistem hukum ini mempunyai yaitu: istilah yang berbeda, namun subyek hukumnya tetap sama, yang diatur hukum internasional adalah individu-individu yang ada suatu negara.

b. Adanya kekuatan hukum yang mengikat. Pada saat diakuinya hukum internasional merupakam suatu sistem hukum tidaklah mungkin dapat dibantah bahwa hukum internasional dan hukum nasional adalah bagian dari satu kesatuan ilmu hukum dan karena itu kedua perangkat hukum tersebut sama-sama mempunyai kekuatan mengikat terhadap individu-individu atau negara. ${ }^{27}$

Mengenai aliran monisme ada dua pandangan yaitu:

a. Primat pada hukum nasional atas hukum internasional

b. Primat hukum internasional atas hukum nasional.

Dari dua aliran tersebut tidak menunjukkan aliran mana yang lebih dominan. Sebaliknya primat hukum internasional atas hukum nasional merupakan syarat yang dibutuhkan untuk keberadaan hukum internasional.

\section{Hukum humaniter sebagai hukum perang}

Hukum perang menurut Mochtar Kusumaatmadja tidak memberikan definisi. hanya pembagian hukum perang menjadi dua

a. Just ad bellum, yaitu hukum tentang perang, mengatur dalam hal bagaimana negara dibenarkan menggunakan kekerasan senjata.

b. Just in bello, yaitu hukum yang berlaku dalam medan perang.

Dan hukum ini dibagi dua, sebagai berikut:

a. Mengatur cara dilakukannya perang (conduct of war), disebut Hague Laws.

b. Mengatur perlindungan orang-orang yang menjadi korban perang, disebut Geneva Law."28

Adapun sumber utama dalam hukum humaniter dapat dijelaskan sebagai berikut:

a. Konvensi-Konvensi Den Haag 1907.

Konvensi ini dihasilkan dalam konferensi Perdamaian yang pertama di Den Haag pada tahun 1899, yang kemudian disempurnakan dalam konferensi kedua tahun 1907. Dalam konvensi Den Haag tersebut mengatur alat dan cara berperang (means and methode of warfare).

Dalam Konferensi Den Haag tahun 1907 ini menghasilkan tiga belas konvensi dan satu deklarasi. ${ }^{29}$ Sebagian dari konvensi tersebut mengatur mengenai perang dilaut. Dan hanya satu konvensi yang mengatur perang di darat yaitu konvensi IV. Perlu dicatat bahwa konvensi IV mempuyai suatu "annex" yaitu yang lazim disebut Hague Regulation

27 Mochtar Kusumaatmadja, Op.cit., hlm. 63.

28 Haryomataram, Pengantar Hukum Humaniter, Rajawali Press, Jakarta, 2012, hlm. 6-7.

29 Konvensi I:"mengenai Penyelesaian Damai Persengketaan Internasional"; Konvensi II: “mengenai pembatasan Kekerasan Senjata dalam menuntut Pembayaran Hutang yang berasal dari Perjanjian Perdata"; Konvensi III: “mengenai Cara Memulai Perang; Konvensi IV mengenaiHukum dan Kebiasaan 
-1907. Ketentuan-ketentuan dalam Hague Regulation inilah yang sampai sekarang menjadi pegangan bagi para belligerents. ${ }^{30}$

b. Konvensi-konvensi Jenewa 1949

Konvensi-konvensi Jenewa, yang juga disebut konvensi-konvensi Palang Merah, terdiri dari empat buku, yaitu: “

1. Konvensi Jenewa tahun 1949 mengenai Perbaikan; Keadaan Anggota Perang yang luka dan sakit di Medan Pertempuran Darat;

2. Konvensi Jenewa tahun 1949 mengenai Perbaikan Keadaan Anggota Perang di Laut yang luka sakit dan Korban Karam;

3. Konvensi Jenewa tahun 1949 mengenai Perlakuan Tawanan Perang;

4. Konvensi Jenewa tahun 1949 mengenai Perlindungan orang-orang Sipil di Waktu Perang. ",31

Kumpulan Konvensi-konvensi jenewa tahun 1949 dikenal dengan Hukum Jenewa. Berbeda dengan Hukum Den Haag yang mengatur alat dan cara berperang, Hukum Jenewa mengatur perlindungan terhadap mereka menjadi korban perang. ${ }^{32}$

Ada beberapa yang penting dalam Konvesi Jenewa secara singkat dijelaskan sebagai berikut:

1. Konvensi Jenewa tahun 1949 selain mengatur perang yang bersifat internasional perang/konflik bersenjata antar negara dan non internasional, perang/konflik bersenjata yang terjadi didaerah salah satu pihak peserta agung, antara pasukannya dengan pasukan pembangkang/pemberontak yang bersenjata.

2. Dalam Konvensi tersebut terdapat yang disebut ketentuan-ketentuan berlaku utama (common Articles), yaitu ketentuan-ketentuan dianggap sangat penting sehingga dicantumkan didalam keempat buku dengan perumusan yang sama.

c. Protokol Tambahan1977

Merupakan penyempurnaan isi dari konvensi Jenewa 1949. Bahwa perlu ditekankan prinsip-prinsip yang ada dalam konvensi Jenewa masih tetap berlaku. Protokol Tambahan 1977 ini terdiri dari dua buku, yaitu:

1. Protokol I, mengatur perang/konflik bersenjata internasional yaitu perang/ konflik bersenjata antar negara.

Perang di Darat dilengkapi dengan Peraturan Den Haag”; Konvensi V: "mengenai Hak dan Kewajiban Negara dan Warganegara Netral dalam Perang di Darat"; Konvensi VI:" mengenai Status Kapal Dagang Musuh pada saat Permulaan Peperangan"; Konvensi VII: "mengenai Status Kapal Dagang menjadi Kapal Perang"; Konvensi VIII: "mengenai Penempatan Ranjau Otomatis di dalam laut; Konvensi IX mengenai Pemboman oleh Angkatan Laut di waktu perang”; Konvensi X:" mengenai Adaptasi Asasasas Konvensi Jenewa tentang Perang di laut"; Konvensi XI. "mengenai Pembatasan Tertentu terhadap Penggunaan Hak Penangkapan dalam Perang Angkatan Laut"; Konvensi XII:” mengenai Mahkamah Barang-Baranag Sitaan"; Konvensi XIII:"mengenai Hak dan Kewajiban Negara Netral dalam perang di laut”

30 Haryomataram, Op.cit., hlm. 45-48.

31 Ibid., hlm. 48.

32 Ibid., hlm. 48-49. 
2. Protokol II, mengatur perang/konflik bersenjata non internasional, yaitu perang/konflik bersenjata terjadi dalam wilayah salah satu pihak anggota agung antara pasukannya dengan pasukan pembangkang atau pemberontak. Protokol Tambahan II ini memberi tambahan isi/ruang lingkup dalam Pasal 3 Konvensi Jenewa. ${ }^{33}$

Protokol tambahan 1977 memuat beberapa ketentuan yang penting/baru, antara lain:

1. Memuat definisi beberapa pengertian penting, yang belum terdapat dalam peraturan sebelumnya, seperti:
a. Kombat;
b. Penduduk Sipil;
c. Sasaran Militer;
d. Sasaran Sipil;

2. Memuat hal-hal baru, seperti:
a. Definisi/pengertian Civil Defense
b. Definisi/pengertian Tentara Bayaran
c. Perang Pembebasan Nasional
d. Ketenttuan mengenai tugas komandan $^{34}$

3. Terbentuknya internasional Fact Finding Commission kewenangan dari komisi ini adalah:

a. Menyelidiki fakta-fakta yang dianggap sebagai pelanggaran berat (grave breaches) atau pelanggaranpelanggaran serius lain;

b. Membantu dengan jalan memberikan jasa-jasa baik, mengembalikan sikap menghormati konvensi dan protokol ini.
Pada waktu meratifikasi protokol ini suatu negara dapat membuat pernyataan bahwa negara tersebut mengakui kewenangan komisi untuk menyelidiki tuduhan (adanya suatu pelanggaran) yang dilakukan salah satu pihak. Jadi pihak peserta agung yang tidak membuat deklarasi tidak mengakui kewenangan

\section{B. Penerapan San Remo Manual dalam Operasi Satgas MTF TNI Pada Misi Unifil}

\section{Latar belakang san remo manual}

Pembaharuan hukum perang di laut ini sudah dimulai pada tahun 1987, dalam Round Table di San Remo yang dilaksanakan oleh International Institute of Humanitarian Law bekerja sama dengan Universitas Pisa dan Universitas Syracuse New York yang membicarakan perlunya memperbarui hukum untuk sengketa bersenjata di laut. Selanjutnya dokumen San Remo Manual ini kemudian dipersiapkan mulai tahun 1988, dokumen San Remo Manual iini disusun karena adanya modernisasi alat utama sistem persenjataan dan metode perang di laut. Sehingga dibutuhkan adanya pengembangan studi tentang penerapan ketentuan hukum pada perang modern di laut.

"New technologies and methods of warfare, new development in the law of armed conflict and in the law of the sea and the increased possibilities of grave harm to the environment 
as a result of armed conflict at sea, require study in the light of the principles [of international law applicable in armed conflict] ${ }^{, 35}$

Adapun alasan mendasar dibentuknya San Remo Manual antara lain ${ }^{36}$ :

1. Hukum perang di laut secara praktis tidak mengalami kemajuan sejak 1907. Instrumen hukum perang di laut yang penting, seperti London Declaration tahun 1909 dan Oxford Manual 1913 belum pernah diratifikasi oleh negaranegara walaupun menjadi cerminan dari kebiasaan internasional yang berlaku pada saat itu. Tetapi, aturan-aturan tersebut telah tidak sesuai lagi untuk kondisi saat ini.

2. Hukum perang di laut secara tradisional didasarkan pada ketentuan hukum perang pada abad-19 ini telah tidak mampu untuk menjawab adanya perkembangan teknologi modern dalam metode dan wahana perang di laut.

3. Hukum konflik bersenjata di darat telah diperbaiki melalui Protokol Tambahan I dan II tahun 1977 sebagai tambahan dari Konvensi Jenewa 1949, dimana beberapa aturan dalam Protokol Tambahan I membawa akibat pada operasi di laut. Walaupun demikian, pada dasarnya aturan tersebut berlaku hanya untuk perang di darat yang membawa akibat di laut, sehingga tidak memadai sebagai pedoman perang di laut.

4. Oleh karena adanya perkembangam di bidang hukum laut, Piagam PBB, hukum lingkungan internasional dan juga hukum udara, maka menjadi pendorong yang kuat untuk dilakukan evaluasi hukum perang di laut.

San Remo Manual ini adalah merupakan suatu bentuk panduan yang unik, karena berisi berbagai bentuk ketentuan, tidak sekedar suatu bentuk kumpulan atau gabungan (compilation) saja. Sebagian besar aturan yang ada pada Manual ini adalah berasal dari ketentuan yang telah disebutkan sebelumnya pada Konvensi Den Haag 1907, Konvensi Jenewa 1949 ataupun pada Protokol Tambahan I 1977. Beberapa bagian lainnya merupakan gabungan panduan praktis negara-negara mengenai perang di laut. Semua ini kemudian disusun dalam bentuk dokumen tertulis dan dinyatakan dalam San Remo Manual, kemudian diberikan penambahan dengan ketentuan lain yang menjadi suatu aturan yang betul-betul baru, terutama mengenai mandala perang di laut karena harus disesuaikan pada UNCLOS $1982 .{ }^{37}$

\footnotetext{
35 Louise Doswald-Beck, San Remo Manual on International Law Applicable to Armed Conflicts at Sea, Prepared by International Lawyers and Naval Experts convened by the HIIHL, Editor, International Institute of Humanitarian Law, Grotius Publications, Cambridge University Press, 1995, hlm. 61.

36 Ibid., hlm. 61-62.

37 Ibid., hlm. 72-73.
} 


\section{Kedudukan san remo manual menurut hukum internasional}

Bahwa suatu manual, model law, guidance atau sejenisnya, berdasarkan dengan tujuan pembuatannya, merupakan suatu panduan bila diteliti dari sudut pandang hukum, jadi manual tidak harus diikuti. Sehingga segala ketentuan yang ada didalamnya tidak mempunyai kekuatan mengikat. Hal ini sangat berbeda dibandingkan dengan suatu perjanjian berlaku azas pacta sunt servada atau suatu perjanjian dibuat secara sah memiliki kekuatan yang mengikat sebagaimana dimiliki oleh suatu undang-undang. Apabila timbul konflik diantara negara-negara pada suatu perang di laut, suatu manual atau pedoman, tidak dapat langsung digunakan menjadi sumber hukum. Agar menjadi manual sebagai sumber hukum maka harus dapat memenuhi kriteria ketentuan pasal 38 ayat 1 Statuta Mahkamah Internasional. ${ }^{38}$

1. Untuk menentukan San Remo Manual dapat digunakan dalam sengketa diantara negara-negara dalam perang dilaut dalam kerangka Hukum Internasional harus memenuhi syarat formal berdasarkan pasal 38 ayat (1) Statuta Mahkamah Internasional. Menurut Prof Mochtar Kusumaatmadja bahwa sumber hukum dalam pasal 38 Statuta Mahkamah Internasional dapat dibagi menjadi dua sumber hukum yaitu: Sumber hukum primer atau utama meliputi hukum perjanjian internasional, hukum kebiasaan internasional dan prinsip hukum umum.

2. Sumber hukum subsidier atau tambahan yaitu keputusan pengadilan dan ajaran sarjana hukum yang terkemuka dari berbagai negara. ${ }^{39}$ Dari ketentuan pasal 38 ayat 1 Mahkamah Internasional, San Remo Manual dapat menjadi sumber hukum Internasional. Menurut penulis, San Remo Manual ini merupakan gabungan dari ketiganya, yaitu Perjanjian Internasional, kebiasaan internasional dan pendapat para sarjana. Sehingga postulasinya akan dapat dijelaskan sebagai berikut:

a. Perjanjian Internasional.

Jika dilihat dari terbentuknya San Remo Manual tidak dapat dikatakan sebagai perjanjian internasional, namun San Remo Manual dapat dijadikan sebagai sumber hukum internasional dengan menjadikan sebagai perjanjian internasional dengan melihat unsur yang mendukung dan tidak mendukung yang dapat mewujudkannya. Unsur yang mendukung adalah sampai saat ini sebagian besar angkatan laut negaranegara yang ada di dunia sudah menggunakan San Remo Manual sebagai acuan, seperti Angkatan Laut Indonesia (TNI AL). Sehingga kemungkinan San Remo Manual dapat dijadikan sebagai perjanjian internasional yang mengikat semua negara. Namun,

38 Enny Narwati, “Aturan Perang Di Laut: San Remo Manual sebagai sumber Hukum Internasional”, Mimbar Hukum, Volume 20 No. 3, Oktober 2008, hlm. 444.

39 Mochtar Kusumaatmadja dan Etty R. Agoes, Op.cit., hlm. 115-116. 
unsur yang tidak mendukung San Remo Manual menjadi perjanjian internasional dikarenakan perang di laut sangat berkaitan dengan keinginan, kepentingan dan tujuan nasional masing-masing negara yang sangat bermacam-macam. Sehingga sulit membuat negara-negara untuk mengadakan sepakat dan menyeimbangkan keinginan, kepentingan dan tujuan nasional yang beraneka ragam. Misalnya UNCLOS 1982 memerlukan lebih dari 10 tahun untuk menjadi konvensi dan mempunyai kekuatan hukum mengikat yang berlaku secara umum. Walaupun sangat sulit untuk San Remo Manual untuk menjadi konvensi, namun bukan hal yang tidak mungkin terjadi melihat sudah banyak negara yang telah memakai aturan dalam San Remo Manual. ${ }^{40}$

b. Kebiasaan Internasional:

Selanjutnya dalam sebagian aturan San Remo Manual merupakan penegasan kembali dari aturan yang ada dalam Konvensi Den Haag 1907, Konvensi Jenewa 1949 dan Protokol tambahan I 1977, dimana sudah berlaku secara umum dan sudah lama sebagai hukum kebiasaan internasional tanpa negara yang bersangkutan meratifikasinya misalnya Konvensi Den Haag dan Konvensi Jenewa yang mengatur tentang peperangan. Suatu aturan agar dapat menjadi kebiasaan internasional mempunyai unsur-unsur ${ }^{41}$ :

\section{Opinio Juris Sive Necessitatis}

Adanya kehendak negara mengakui dan menerima kebiasaan internasional menjadi suatu hukum kebiasaan internasional. Di dalam aturan San Remo Manual secara umum telah memenuhi syarat, sampai dengan sekarang tidak adanya protes dari negara-negara yang angkatan lautnya sudah menggunakan San Remo Manual.

2. Lamanya waktu praktek suatu kebiasaan internasional.

Tidak ada masalah yang berarti, karena dalam keadaan tertentu dapat dikesampingkan. Misalnya aturan dalam San Remo Manual tentang perang dilaut sudah beberapa kali digunakan mengenai penggunaan zona ${ }^{42}$ dan kawasan operasi atau berubah menjadi Area of Maritime Operation (AMO) setelah adanya resolusi PBB untuk upaya penghentian konflik, dan tidak ada satupun negara dalam prakteknya yang bertentangan dengan aturan tersebut.

3. Keseragaman dan konsistensi

Bahwa aturan dalam San Remo Manual sesuai syarat ini, dengan banyak angkatan laut negara-negara menggunakannya sebagai aturan perang di laut dan tidak adanya pertentangan didalamnya.

4. Berlaku secara umum

Walaupun San Remo Manual masih dalam bentuk manual, dalam prakteknya sudah

40 Enny Narwati, Op.cit., hlm. 445.

41 Mochtar Kusumaatmadja dan Etty R. Agoes, Op.cit., hlm. 144-145.

42 Pasal 105 San Remo Manual: "Pihak yang berperang tidak dapat membebaskan dirinya dari kewajiban Hukum Humaniter Internasional dengan menetapkan zona-zona yang dapat bertentangan dengan penggunaan yang sah dari zona-zona tersebut". 
dijadikan pedoman bagi seluruh angkatan laut dari negara-negara di dunia, termasuk TNI AL.

c. Pendapat para ahli.

Bahwa dalam aturan yang baru dibuat dan tidak pernah dipraktekan serta digunakan oleh negara-negara, oleh karena itu hal ini dapat kita pandang sebagai ajaran para ahli. Sebagaimana yang dimaksud dalam pasal 38 ayat (1) huruf d Statuta Mahkamah Internasional, San Remo Manual dibuat oleh para ahli dibidang hukum dan perang terkemuka di dunia yang dipelopori oleh Institude of International Humanitarian Law yang berpusat di Jenewa yang mendapat dukungan sepenuhnya dari International Commitee of the Red Cross (ICRC) yang memang tanggap terhadap perkembangan Hukum Humaniter International.

Dapat dikatakan bahwa peserta penyusun San Remo Manual telah mewakili berbagai belahan dunia dan berbagai profesi yang berhubungan satu dengan yang lainnya, yang adalah kristalisasi dari pendapat para ahli yang terkemuka, sehingga San Remo Manual dapat digunakan sebagai sumber hukum internasional tambahan. ${ }^{43}$

\section{Penerapan san remo manual dapat digunakan dalam operasi satgas MTF TNI}

Bagi Negara Indonesia, sampai dengan saat ini San Remo Manual sudah digunakan khususnya oleh TNI AL. Dapat kita lihat dari berbagai kegiatan dokumen yang menggunakan referensi San Remo Manual antara lain sebagai berikut:

1. Mabes TNIAL bekerjasama dengan ICRC pada tahun 2002 telah menerjemahkan San Remo Manual ke dalam bahasa Indonesia.

2. Mabes TNI AL dengan ICRC tahun 2003 telah membuat buku ajar berperang dengan benar yang ditujukan kepada segenap prajurit TNI AL

3. Sosialisasi yang sudah dilakukan oleh TNI AL kepada prajurit TNI AL dan staf pengajar di perguruan tinggi seluruh Indonesia. ${ }^{44}$

4. Mengeluarkan Dokumen Aturan Pelibatan bagi unsur-unsur TNI AL di laut pada masa damai berdasarkan surat keputusan Kasal nomor Skep/635/ III/2004, tanggal 12 Maret 2004 ${ }^{45}$.

5. Termasuk juga didalam Satgas MTF TNI misi UNIFIL. Dalam keterlibatan satgas MTF TNI ini kedudukan KRI adalah merupakan representasi Indonesia sebagai pihak netral atau negara yang tidak terlibat dalam konflik, ${ }^{46}$ sesuai dengan pasal 13 poin d (netral) San Remo Manual yang mendapat mandat PBB untuk menangani konflik bersenjata internasional yang telah ditetapkan

\footnotetext{
43 Enny Narwati, Op.cit., hlm. 456.

44 Ibid., hlm. 319.

45 Mabes TNI AL, PUM-1.01.139., Buku Petunjuk Operasi Aturan Pelibatan Bagi Unsur-unsur TNI AL di Laut pada Masa Damai., Mabes TNI AL Cilangkap, Jakarta 2004, hlm. 5.

46 Pasal 13 huruf d San Remo Manual:"Netral berarti negara yang tidak terlibat dalam konflik."
} 
DK PBB sesuai dengan resolusi 1701. Dimana DK PBB telah mengambil tindakan pencegahan sesuai dengan Bab VII piagam PBB. ${ }^{47}$

Berikut akan dijelaskan beberapa pasal penerapan ketentuan dalam San Remo Manual yang digunakan Satgas MTF TNI:

1. Sesuai pasal 9 San Remo Manual, ${ }^{48}$ DK PBB mengambil keputusan untuk menggunakan kekuatan bersenjata termasuk Indonesia yang memenuhi undangan sebagai Troop Contributing Countries/TCC yang mendapat kewenangan untuk menggunakan kekuatan militer dalam mencegah timbulnya kembali konflik di wilayah perairan Lebanon.

2. Dalam pasal 2 San Remo Manual, kedudukan Satgas MTF TNI adalah dibawah perlindungan dan otoritas PBB, dimana Satgas MTF TNI melaksanakan mandat dari resolusi 1701 DK PBB.

3. Pasal 3 dari San Remo ini menjadi dasar kuat Satgas MTF TNI dalam memberlakukan aturan pelibatan (ROE/ Rule of Enggagement) yang digunakan. Dimana hak pembelaan diri diijinkan untuk dilakukan sesuai pasal 51 piagam
PBB. Apabila suatu serangan bersenjata dari pihak yang bertikai atau pihak lainnya dapat merugikan atau membahayakan keselamatan Satgas MTF TNI maka secara proporsional (Pasal 4 San Remo) Satgas MTF TNI dapat melakukan tindakan perlawanan. Dalam pasal 13 dijelaskan bahwa kedudukan Satgas MTF TNI adalah representasi Indonesia sebagai negara netral dalam konflik antara Lebanon-Israel yang diberi mandat PBB untuk memelihara perdamaian sehingga konflik atau perang Lebanon-Israel tidak pecah lagi atau menjadi lebih buruk dan meluas.

\section{Simpulan}

A. Status Hukum Satgas MTF TNI adalah legal yang berdasarkan:

1. Hukum Nasional: Alinea ke IV Pembukaan UUD 1945, Pasal 1 ayat (2), Pasal 1 ayat (3), Pasal 10 UndangUndang RI Nomor 37 Tahun 1999 tentang Hubungan Luar Negeri, Pasal 10 ayat (3), Pasal 12, 14 ayat (1) Undang-Undang RI Nomor 3 Tahun 2002 tentang Pertahanan Negara, Pasal 3, Pasal 5, Pasal 7 ayat (2) huruf b angka 6, Pasal 9, Pasal 17,

47 Pasal 8 San Remo Manual: "Dalam hal penangan suatu konflik bersenjata internasional, apabila Deawan Keamananan PBB telah mengambil tindakan pencegahan atau penegakan dengan menerapkan tindakan ekonomi berdasarkan Bab VII Piagam PBB, negara-negara PBB tidak dapat mendasarkan hukum netralitas untuk membenarkan tindakan yang tidak sesuai dengan kewajibannya berdasarkan Piagam PBB atau brdasarkan keputusan Dewan Keamanan PBB."

48 Pasal 9 San Remo Manual:’Dengan tunduk kepada ketentuan paragraf 7, dimana Dewan Keamanan PBB telah mengambil keputusan untuk menggunakan kekauatn bersenjata, atau memberikan wewenang penggunaan kekuatan bersenjata kepada negara tertentu atau kelompok negara tertentu, ketentuanketentuan yang diatur ini dan ketentuan-ketentuan lain dari hukum humaniter internasional yang berlaku pada konflik bersenjata di laut harus diberlakukan kepada pihak-pihak yang bersengketa terhadap berbagai konflik yang mungkin terjadi." 
Pasal 20 ayat (2) Undang-Undang RI Nomor 34 Tahun 2004 tentang TNI, Keputusan Presiden Nomor 15 Tahun 2006 tentang Kontingen Garuda dalam Misi Perdamaian di Lebanon

2. Hukum Internasional: Chapter VI dan VII Piagam PBB/ UN Charter, Resolusi 1701 Dewan Keamanan PBB, Pasal 29 UNCLOS 1982, Ketentuan dalam Konvensi Jenewa 1949 dan Protokol Tambahan yang mengatur tentang Hukum Humaniter/Perang, Pasal 10, Pasal 13 huruf d San Remo Manual.

B. Penerapan San Remo Manual dapat digunakan dalam Operasi Satgas MTF TNI yang terdapat dalam pasal-pasal antara lain:

1. Pasal 2 San Remo Manual, kedudukan Satgas MTF TNI adalah dibawah perlindungan dan otoritas $\mathrm{PBB}$, yang melaksanakan mandat dari Resolusi Dewan Keamanan PBB

2. Pasal 9 San Remo Manual, Dewan Keamanan PBB mengambil keputusan untuk menggunakan kekuatan bersenjata termasuk Indonesia sebagai Troop Contributing Countries (TCC) mendapat kewenangan untuk menggunakan kekuatan militer dalam mencegah timbulnya kembali konflik di wilayah perairan Lebanon.

3. Pasal 13 huruf d San Remo Manual, Kedudukan KRI yang bertugas sebagai Satgas MTF TNI di wilayah Lebanon merupakan representasi wilayah kedaulatan negara Indonesia di wilayah konflik yang sewaktu-waktu dapat menghadapi situasi konflik sehingga harus menerapkan aturan pelibatan dan sesuai piagam PBB memiliki proteksi imunitas sebagai pasukan pemelihara perdamaian PBB. Sejak tahun 2009 pengiriman Satgas MTF TNI yang pertama masih belum terdapat aturan pelibatan yang secara khusus digunakan untuk memproteksi dari kemungkinan terjadi konflik terbuka antara pihak-pihak yang bertikai.

\section{DAFTAR PUSTAKA}

\section{Buku}

Departemen Pertahanan RI, 2007, Strategi Pertahanan, Departemen Pertahanan, Peraturan Menteri Pertahanan Nomor: Per/22 /M/ XII/2007 tanggal 28 Desember 2007, Dephan, Jakarta.
Dyah Ochtorina susanti dan A'an Efendi, 2014, Metode Penelitian Hukum, Sinar Grafika, Jakarta.

Darji Darmodiharjo dan Sidharta, 2004, Pokok-pokok Filsafat Hukum, Apa dan Bagaimana Filsafat Indonesia, Gramedia Pustaka Utama, Jakarta. 
Haryomataram, 2012, Pengantar Hukum

Humaniter, Rajawali Press, Jakarta.

Johny Ibrahim, 2008, Teori dan Metodologi

Penelitian Hukum Normatif, Bayu

Media Publishing, Malang.

Louise Doswald-Beck, 1995, San Remo

Manual on International Law

Applicable to Armed Conflicts at Sea,

Prepared by International Lawyers

and Naval Experts convened by

the HIIHL, Editor, International

Institute of Humanitarian Law, Grotius

Publications, Cambridge University

Press.

Mochtar Kusumaatmadja dan Etty R.

Agoes, 2010, Pengantar Hukum

Internasional, Ed. 2, Cetakan ke-2,

Alumni, Bandung.

Mabes TNI AL, 2012, Doktrin Eka Sasana

Jaya, Mabes TNI AL, Jakarta.

Mabes TNI, 2008, Buku Petunjuk Induk

tentang Operasi TNI, Peraturan

Panglima Nomor Perpang/31/V/2008

tanggal 22 Mei 2008, Mabes TNI,

Jakarta.

Peter Mahmud Marzuki, 2005, Penelitian

Hukum, Kencana Prenada Media

Group, Jakarta.

Soejono Soekanto, 2003, Pengantar

Penelitian Hukum, UI Press, Jakarta.

Salim dan Arlies Septiana Nurbani, 2010,

Penerapan Teori Hukum pada

Penelitian Tesis dan Desertasi,

RajaGrafindo Persada, Jakarta.
Suratman dan Philips Dillah, 2013, Metode

Penelitian Hukum, Alfabeta, Bandung.

Zainuddin, 2009, Metode Penelitian Hukum, Sinar Grafika, Jakarta.

\section{Jurnal}

Enny Narwaty, 2012, Keberadaan San Remo

Manual 1994 dalam Kaitannya

dengan UNCLOS 1982, Perspektif

Volome XV No. 3.

Enny Narwaty, 2008, Aturan Perang di laut:

San Remo Manual sebagai sumber

Hukum Internasional, Mimbar

Hukum, Volume 20 No. 3, Edisi Juli 2012.

\section{Makalah}

Didong Rio Duta, 2010, Laporan Pelaksanaan Tugas sebagai perwira Staf Naval Operation Center/NOC UNIFIL, Mabes TNI, Jakarta.

KRI Sultan Iskandar Muda-367, 2014, Rencana Operasi Satgas MTF TNI Konga XXVIII-F/UNIFIL, Koarmatim, Surabaya.

KRI Frans Kaisiepo - 368, 2013, Laporan Pelaksanaan Tugas Satgas MTF TNI Konga XXVIII-E/UNIFIL 2013 (MTF-5), Koarmatim, Surabaya.

\section{Peraturan Perundang-undangan}

Undang-undang Republik Indonesia Nomor 37 Tahun1999 tentang Hubungan Luar Negeri. 
Undang-undang Republik Indonesia Nomor

3 Tahun 2002 tentang Pertahanan Negara.

Undang-undang Republik Indonesia Nomor

34 Tahun 2004 tentang Tentara

Nasional Indonesia.

Kepres Nomor 15 Tahun 2006 tentang

Kontingen Garuda Dalam Misi

Perdamaian di Lebanon.

Kepala Staf TNI AL, 2015, Telegram

Kasal Nomor 130/Sops/0215

TWU0203.1955 tentang Penunjukan

KRI Bung Tomo-357 sebagai kapal kelas MRLF yang akan menggantikan KRI Sutan Iskandar -357dari kelas SIGMA dalam Satgas Konga XXVIII-H/MTF TNI, Sopsal, Jakarta.

Piagam PBB/ UN Charter.

San Remo Manual.

Surat Kabar

Yayan Sugiyana, 2014, Prajurit TNI Angkatan Laut dalam Misi Maritime Task Force (MTF), Majalah Cakrawala. 